\title{
ДЕЯКІ ПОКАЗНИКИ БІЛКОВОГО ОБМІНУ В ЩУРІВ, ОТРУЄНИХ БЛІДОЮ ПОГАНКОЮ
}

Вступ. Бліда поганка (Amanita phalloides) є одним із найнебезпечніших отруйних грибів. Токсини блідої поганки належать до сильних отрут, а з огляду на відсутність специфрічних антидотів до них, лікування отруєнь цим грибом залишається важливою проблемою. Тяжка клінічна картина отруєнь блідою поганкою зумовлена токсичним ураженням печінки і нирок, розвитком гострого гастроентероколіту, виникненням ендотоксикозу, пов'язаного з порушенням показників гомеостазу і накопиченням в організмі токсичних речовин ендогенного походження.

Мета дослідження - вивчити вплив отрути блідої поганки на деякі показники білкового обміну в щурів.

Методи дослідження. Дослідження проводили на нелінійних білих 18-24-місячних щурах-самцях (період старості; старі). Отруювали тварин шляхом одноразового внутрішньочеревного введення їм екстракту блідої поганки, отриманого за методом H. Wieland, у дозі 85 мг/кг маси тіла. Евтаназію щурів здійснювали шляхом декапітації під тіопенталовим наркозом через 6, 24 та 72 год після отруєння з подальшим забором крові. У сироватці крові визначали концентрацію загального білка та білкових орракцій, креатиніну і сечовини. Стан ендогенної інтоксикації оцінювали за еритроцитарним індексом інтоксикації (EII) та вмістом молекул середньої маси.

Результати й обговорення. Встановлено, що отруєння експериментальних тварин токсинами блідої поганки призводило до суттєвих порушень білкового обміну. Найбільш виражені зміни показників білкового обміну спостерігали через 72 год з моменту інтоксикації. У щурів відзначали зниження концентрації сечовини, підвищення концентрації креатиніну, гіпопротеїнемію, гіпоальбумінемію, зменшення вмісту $\alpha_{1}$ - $i \alpha_{2}$-глобулінів та зростання вмісту $\beta$ - $і$ ү-глобулінів. Найбільш виражені зміни показників ендогенної інтоксикації були характерні через 24 год з моменту інтоксикації.

Висновки. Отримані результати свідчать про різкий негативний вплив аманіта-сралоїдинів на білоксинтезувальний апарат гепатоцитів. Прогресування патологічного процесу в печінці та зниження компенсаторних можливостей призводять до ендотоксикозу, на що вказує зростання в динаміці показників ендогенної інтоксикації - еритроцитарного індексу інтоксикації та вмісту молекул середньої маси.

КЛЮЧОВІ СЛОВА: бліда поганка; отруєння; білковий обмін; щури.

ВСТУП. Щорічно на території нашої країни реєструють випадки гострих отруєнь отруйними грибами. За тяжкістю клінічного перебігу ці отруєння займають провідне місце серед всіх небактерійних харчових отруєнь.

Бліда поганка (Amanita phalloides) $є$ одним із найбільш отруйних грибів, які в більшості випадків викликають смертельні отруєння. Цей вид містить три групи токсинів: аматоксини, фралотоксини і віротоксини. 3 них основними $€$ аматоксини, особливо $\alpha$-аманітин, вони відповідальні за токсичні ефекти в людей. Доведено, що а-аманітин інгібує РНК-полімеразу II, що викликає порушення транскрипції мРНК. У результаті гепатоцити не можуть синтезувати ключових ○І. П. Кузьмак, 2018. генів, які кодують білок, що призводить до розпаду ядер і патологічного центрилобулярного некрозу печінки. Печінка є основним органом-мішенню токсичності, що спричиняє підступний початок печінкової недостатності протягом 48 год. Токсична дія фралотоксинів пов'язана з їх впливом на мембрани й органели гепатоцитів, епітелію та судин кишечника. Симптоми інтоксикації включають шлунково-кишкові розлади, які супроводжуються жовтяницею, судомами і комою, що призводить до смерті. Відкриття ефективного антидоту все ще залишається основним невирішеним питанням [1, 2].

Мета дослідження - з'ясувати динаміку змін деяких показників білкового обміну в щурів при аманіта-сралоїдиновому отруєнні. 
МЕТОДИ ДОСЛІДЖЕННЯ. Дослідження проводили на нелінійних білих 18-24-місячних щурах-самцях (період старості; старі) [3].

Під час виконання досліджень усі тварини перебували у віварії Тернопільського державного медичного університету імені І. Я. Горбачевського на стандартному раціоні відповідно до санітарно-гігієнічних норм.

Утримували щурів і проводили всі експерименти на них із дотриманням національних (Закон України № 3447-IV "Про захист тварин від жорстокого поводження", 2006) та міжнародних (Європейська конвенція про захист хребетних тварин, що використовуються для дослідних та інших наукових цілей, Страсбург, 1986) загальних правил і рекомендацій щодо гуманного поводження з лабораторними тваринами [4-6].

Отруювали тварин шляхом одноразового внутрішньочеревного введення їм екстракту блідої поганки, отриманого за методом H. Wieland [7], у дозі 85 мг/кг маси тіла. Евтаназію щурів здійснювали шляхом декапітації під тіопенталовим наркозом через 6, 24 та 72 год після отруєння з подальшим забором крові.

Стан білкового обміну оцінювали за концентрацією загального білка та білкових фрракцій у сироватці крові. Вміст загального білка визначали біуретовим методом [8]. 3 метою дослідження білкових фрракцій використовували діагностичний набір для електрофроретичного розділення білків сироватки крові на агарозі "Cormay gel protein 100" виробництва фрірми "Cormay" (Австрія).

Стан ендогенної інтоксикації оцінювали за еритроцитарним індексом інтоксикації (EII) та вмістом молекул середньої маси (МСМ) [9].

Еритроцитарний індекс інтоксикації визначали за методикою, в основі якої лежать уявлення про еритроцити як універсальний адсорбент, що дозволяє оцінити рівень ендогенної інтоксикації за зміною сорбційної здатності еритроцитів полярного, практично не проникного через їх мембрану метиленового синього.

Концентрацію креатиніну та сечовини - показників екскреторної функції нирок визначали із застосуванням наборів реактивів "Філісіт-Діагностика" (Україна) відповідно до інструкції фрірми-виробника.

Статистичну обробку цисррових даних здійснювали за допомогою програмного забезпечення Excel ("Microsoft", США) і STATISTICA 6.0 ("Statsoft", США) з використанням непараметричних методів оцінки одержаних даних. Для всіх показників розраховували значення середньої арисрметичної вибірки (М), ії дисперсії і помилки середньої $(\mathrm{m})$. Достовірність різниці значень між незалежними кількісними величинами встанов- лювали за допомогою критерію Манна - Уїтні. Зміни вважали статистично достовірними при $p<0,05[10]$.

РЕЗУЛЬТАТИ Й ОБГОВОРЕННЯ. ВвеДеННЯ тваринам екстракту блідої поганки призводило до суттєвих порушень білкового обміну, що відображено в таблиці. Так, у 18-24-місячних щурів, отруєних цим грибом, концентрація загального білка в сироватці крові зменшувалась на 41 \% порівняно з показником інтактних тварин через 72 год 3 моменту введення отрути блідої поганки.

Крім концентрації загального білка в сироватці крові, важливим показником, що характеризує фрункцію печінки, є концентрація альбумінів та глобулінів, особливо співвідношення між цими показниками.

За умов отруєння організму тварин токсинами блідої поганки, крім загальної гіпопротеїнемії, в крові щурів спостерігали виражену гіпоальбумінемію.

Як і у випадку з концентрацією загального білка в крові, максимальне достовірне зниження альбумінів (на 40 \% порівняно з інтактними тваринами) мало місце в крові старих щурів через 72 год після інтоксикації. Вищенаведені результати можна пояснити інгібуючим впливом аманіта-фралоїдинів на альбуміносинтезувальну функцію гепатоцитів, оскільки відомо, що всі альбуміни крові синтезуються в печінці.

Спостерігали достовірне зниження рівня $\alpha_{1}-$ та $\alpha_{2}$-глобулінів, при цьому мінімальні показники зафріксовано через 72 год після інтоксикації - 50 і 57 \% відповідно порівняно з інтактними тваринами. Концентрація $\beta$ - та у-глобулінів, порівняно 3 контролем, достовірно підвищувалася через 6, 24 та 72 год після інтоксикації - на 36, 53 і 61 \% (३-глобуліни) та на 35, 68 і 87 \% (у-глобуліни).

Беручи до уваги те, що 75-90 \% $\alpha_{1}$ - та $\alpha_{2}$-глобулінів синтезується в гепатоцитах, зниження їх вмісту при введенні аманіта-фралоїдину можна пояснити тяжкими деструктивними процесами в печінці, які виникають при дії отрути блідої поганки.

У даному випадку підвищення вмісту в крові у-глобулінів, яке вказує на активізацію гуморального імунітету, є проявом запального синдрому, що виникає при дії токсину блідої поганки на організм.

Альбуміно-глобуліновий коесріцієнт (співвідношення кількості альбумінів до кількості глобулінів) $€$ цінним діагностичним показником стану білкового обміну в організмі. Низькі значення цього параметра призводять до зменшення онкотичного тиску крові, внаслідок чого можуть розвиватися набряки тканин. Як видно з табли- 
ці, в уражених аманіта-фралоїдином щурів різко знижувався альбуміно-глобуліновий коефріцієнт порівняно з таким у здорових тварин. Таке зменшення можна пояснити, з одного боку, пригніченням білоксинтезувального апарату гепатоцитів, а з іншого - активізацією імунологічної реакції організму на дію токсину [11].

3 метою встановлення ступеня метаболічного інтоксикаційного синдрому було вирішено дослідити маркери ендогенного токсичного синдрому - молекули середньої маси та еритроцитарний індекс інтоксикації.

Якпоказали отримані результати досліджень (табл.), при дії отрути блідої поганки на організм щурів вміст МСМ у крові був підвищений в усі терміни експерименту - від 6-ї до 72-ї год. Не на однаковому рівні у тварин перебували і показники $\mathrm{MCM}_{1}$ та $\mathrm{MCM}_{2}$, які відображали, відповідно, вміст ланцюгових та ароматичних амінокислот у середньомолекулярних пептидах і продуктах їх розпаду.

Уже на 6-ту год досліджень вміст MCM $_{1}$ та $\mathrm{MCM}_{2}$ в крові уражених 18-24-місячних щурів збільшувався у 2,1 та 2,6 раза відповідно порівняно $з$ інтактними тваринами.

Найбільш виражені зміни вмісту обох фрракцій МСМ спостерігали через 24 год з моменту аманіта-фралоїдинової інтоксикації. Так, вміст $\mathrm{MCM}_{1}$ та $\mathrm{MCM}_{2}$ у цей період збільшився у 18-24-місячних щурів у 2,8 і 3,8 раза відповідно відносно інтактних тварин.

Таким чином, під впливом отрути блідої поганки відмічали підвищення концентрації в крові як $\mathrm{MCM}_{1}$, так і $\mathrm{MCM}_{2}$. Причому зростання молекул середньої маси було значнішим для пулу $\mathrm{MCM}_{280}$, що вказувало на виражене збільшення ароматичних амінокислот у складі середніх молекул. Оскільки середні молекули - мар- кери ендотоксикозу, то різке підвищення їх вмісту свідчило про пік розвитку та генералізації синдрому ендогенної інтоксикації. Інтоксикаційний синдром, спричинений аманіта-оралоїдиновою інтоксикацією, супроводжувався і викликав підвищений розпад тканин, посилення катаболічних процесів унаслідок накопичення надлишкової кількості біологічно активних речовин, деорормованих білкових метаболітів та інших токсичних речовин ендогенного походження.

Збільшення вмісту $\mathrm{MCM}_{1}$, до складу яких можуть входити олігопептиди, сррагменти нуклеїнових кислот, вищих жирних кислот, триацилгліцеролів, холестеролу, свідчило про порушення структури мембран гепатоцитів, а МСM $_{2}$, компонентами яких можуть бути пуринові основи, сечова кислота й ароматичні амінокислоти, - про пригнічення детоксикуючої функції печінки.

Одночасно зі збільшенням у крові тварин, отруєних блідою поганкою, кількості МСМ зростав і сумарний токсичний вплив на мембрани еритроцитів, який проявлявся достовірним підвищенням EII в усі терміни експерименту.

Як видно з таблиці, отрута блідої поганки призводила до достовірного збільшення Ell вже на 6-ту год після інтоксикації - в 1,7 раза порівняно з контрольною групою щурів, на 24-ту год у 2,5 раза порівняно з інтактними тваринами. До кінця досліджень даний показник дещо знизився, але залишався вищим від норми. Ці зміни, очевидно, викликані тим, що при дії отрути на організм порушуються енергетичний обмін і транспорт речовин в еритроцитах, зростає проникність їх мембран та збільшується сорбційна здатність. Таким чином, ступінь деструкції мембран еритроцитів протягом експерименту був найвищим на 24-ту год, це можна пояснити сумарним токсичним ефектом дії фралотоксинів та

Таблиця - Біохімічні показники сироватки крові 18-24-місячних щурів

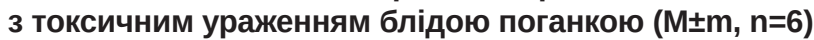

\begin{tabular}{|c|c|c|c|c|c|}
\hline \multirow{4}{*}{\multicolumn{2}{|c|}{ Показник }} & \multicolumn{4}{|c|}{ Група тварин } \\
\hline & & \multirow{3}{*}{ інтактні } & \multicolumn{3}{|c|}{ уражені блідою поганкою } \\
\hline & & & \multicolumn{3}{|c|}{ термін після отруєння, год } \\
\hline & & & 6 & 24 & 72 \\
\hline \multicolumn{2}{|c|}{ Загальний білок, г/л } & $67,17 \pm 1,41$ & $60,03 \pm 1,35^{\star}$ & $43,45 \pm 1,20^{*}$ & $39,77 \pm 0,73^{\star}$ \\
\hline \multicolumn{2}{|l|}{ Альбуміни, \% } & $47,53 \pm 2,30$ & $39,60 \pm 0,97^{*}$ & $33,15 \pm 0,88^{*}$ & $28,38 \pm 0,88 *$ \\
\hline \multirow[t]{4}{*}{ Глобуліни, \% } & $\mathrm{\alpha}_{1}$-глобуліни & $8,05 \pm 0,36$ & $5,25 \pm 0,36^{*}$ & $4,38 \pm 0,18^{*}$ & $4,02 \pm 0,15^{\star}$ \\
\hline & $\alpha_{2}$-глобуліни & $7,40 \pm 0,28$ & $5,47 \pm 0,30^{\star}$ & $4,45 \pm 0,30^{*}$ & $4,18 \pm 0,31^{*}$ \\
\hline & $\beta$-глобуліни & $18,02 \pm 0,56$ & $24,58 \pm 0,62^{*}$ & $27,48 \pm 0,68^{\star}$ & $28,98 \pm 1,77^{*}$ \\
\hline & У-глобуліни & $17,68 \pm 0,80$ & $23,93 \pm 0,54^{*}$ & $29,67 \pm 0,74^{\star}$ & $33,10 \pm 1,50 *$ \\
\hline \multicolumn{2}{|c|}{ Альбуміни/глобуліни } & $0,93 \pm 0,04$ & $0,67 \pm 0,02$ & $0,51 \pm 0,02$ & $0,41 \pm 0,02$ \\
\hline \multicolumn{2}{|l|}{$\mathrm{MCM}_{1}$} & $0,272 \pm 0,020$ & $0,561 \pm 0,045^{\star}$ & $0,767 \pm 0,030 *$ & $0,685 \pm 0,010^{*}$ \\
\hline \multicolumn{2}{|l|}{$\mathrm{MCM}_{2}$} & $0,189 \pm 0,011$ & $0,493 \pm 0,026^{\star}$ & $0,722 \pm 0,039 *$ & $0,567 \pm 0,026^{*}$ \\
\hline \multicolumn{2}{|l|}{ Ell, \% } & $61,9 \pm 2,9$ & $106,0 \pm 4,3^{*}$ & $151,5 \pm 7,7^{*}$ & $131,8 \pm 9,0^{*}$ \\
\hline \multicolumn{2}{|c|}{ Сечовина, ммоль/л } & $6,83 \pm 0,32$ & $4,68 \pm 0,34^{*}$ & $4,13 \pm 0,25^{*}$ & $3,27 \pm 0,18^{*}$ \\
\hline \multicolumn{2}{|c|}{ Креатинін, ммоль/л } & $6,52 \pm 0,47$ & $8,95 \pm 0,60^{*}$ & $13,79 \pm 1,05^{\star}$ & $14,05 \pm 0,98^{*}$ \\
\hline
\end{tabular}

Примітка. * - достовірні відмінності порівняно з інтактними тваринами $(p<0,05)$. 
аманітатоксинів, що призводить до патологічного збільшення проникності біологічних мембран, а також сприяє потраплянню токсичних речовин у тканини та клітини життєво важливих органів.

Під впливом отрути блідої поганки в організмі щурів зменшувалась концентрація сечовини у всі терміни експерименту, що свідчило про зниження детоксикаційної фрункції печінки. Так, концентрація сечовини в сироватці крові через 6, 24 та 72 год після ураження цим грибом знизилась (на 31,5; 39,5 і 52,1 \% відповідно до термінів) порівняно 3 контролем.

Зменшення вмісту сечовини в сироватці крові при досліджуваній патології може свідчити про пригнічення сечовиноутворювальної функції печінки внаслідок інтенсивного розпаду гепатоцитів.

Вміст креатиніну в сироватці крові щурів після моделювання отруєння достовірно збільшувався у всі терміни експерименту відносно контролю, причому максимальні зміни спостерігали через 72 год після отруєння (у 2,2 раза), що вказувало на значне порушення фрункціонального стану нирок та розвиток гострої ниркової недостатності, а також можливої хронічної фрорми ниркової недостатності.

ВИСНОВКИ. 1. Отруєння блідою поганкою призводить до виражених змін показників білкового обміну в щурів, при цьому найбільш виражені зміни спостерігають у досліджуваних тварин через 72 год 3 моменту інтоксикації. Порушення білкового метаболізму проявляється гіпопротеїнемією, гіпоальбумінемією, диспротеїнемією за рахунок зменшення вмісту $\alpha_{1}-$ i $\alpha_{2}$-глобулінів та зростання фрракцій $\beta$ - і у-глобулінів. Ці зміни свідчать про виражений негативний вплив аманіта-фралоїдинів на білоксинтезувальний апарат гепатоцитів.

2. Виражені зміни показників ендогенної інтоксикації - еритроцитарного індексу інтоксикації та вмісту молекул середньої маси вказують на нагромадження ендотоксинів в організмі тварин (ендотоксикоз).

3. Отримані результати свідчать про підвищення інтенсивності катаболічних процесів в отруєному організмі, яке супроводжується деструкцією білкових молекул і зростанням вмісту кінцевих продуктів азотного обміну (креатиніну), що вказує на значне порушення функціонального стану нирок та розвиток гострої ниркової недостатності.

Перспективи подальших досліджень. Проведення біохімічних досліджень 3 метою виявлення метаболічних порушень, зокрема білкового обміну, за умов ураження токсинами блідої поганки є актуальною проблемою, яка вимагає поглибленого різностороннього вивчення, що необхідно для прогнозування тяжкості перебігу патологічного процесу, пошуку та розробки методів лікування таких отруєнь.

\section{СПИСОК ЛІТЕРАТУРИ}

1. Amanita phalloides poisoning: mechanisms of toxicity and treatment / / J. Garcia, V. M. Costa, A. Carvalho [et al.] // Food Chem. Toxicol. - 2015. - 86. P. 41-55. DOI:10.1016/j.fct.2015.09.008

2. Horowitz B. Z. Amatoxin mushroom toxicity / B. Z. Horowitz M. J. Moss. Mode access : https://www. ncbi.nlm.nih.gov/books/NBK431052/

3. Нариси вікової токсикології / за ред. І. М. Трахтенберга. - К. : Авіцена, 2005. - 256 с.

4. Про захист тварин від жорстокого поводження : Закон України від 21.02.2006 р. № 3447-IV.

5. Науково-практичні рекомендації з утримання лабораторних тварин та роботи з ними / Ю. М. Кожем'якін, О. С. Хромов, М. А. Філоненко, Г. А. Сайсретдінова. - К. : Авіцена, 2002. - 156 с.

6. European convention for the protection of vertebrate animals used for experimental and other scientific purposes. - Council of Europe. Strasbourg, 1986. No. $123 .-52 \mathrm{p}$

7. Wieland $\mathrm{H}$. Uber die Giftstoffe des Knollenblatterpilzes. VI. Amanitin, das Hauptgift des Knollenblatterpilzes / H. Wieland, R. Hallermayer // Liebig's Ann. Chem. 1941. - No. 548. - P. 1-18.

8. Горячковский А. М. Клиническая биохимия в лабораторной диагностике / А. М. Горячковский. Одесса : Экология, 2005. - 616 с.

9. Методи дослідження ендогенної інтоксикації організму : метод. рек. / [М. А. Андрейчин, М. Д. Бех, В. В. Дем'яненко та ін.]. - К., 1998. - 31 с.

10. Rosner B. Fundamentals of Biostatistics / B. Rosner. - Boston, USA. - 2010. - 859 p.

11. Кузьмак І. П. Особливості білкового складу крові при аманіта-сралоїдиновому отруєнні / І. П. Кузьмак // Експерим. та клініч. фрізіологія і біохімія. -2012. № 2. - C. 44-49. 


\section{REFERENCES}

1. Garcia, J., Costa, V.M., \& Carvalho, A. (2015). Amanita phalloides poisoning: mechanisms of toxicity and treatment. Food Chem. Toxicol., 86, 41-55. DOI:10.1016/j.fct.2015.09.008

2. Horowitz, B.Z., \& Moss, M.J. Amatoxin mushroom toxicity. Retrieved from: https://www.ncbi.nlm.nih.gov/ books/NBK431052/

3. Trakhtenberh, I.M. (Ed.). (2005). Narysy vikovoi toksykolohii [Essays on age toxicology]. Kyiv: Avitsena [in Ukrainian].

4. Zakon Ukrainy "Pro zakhyst tvaryn vid zhorstokoho povodzhennia" vid 21.02.2006 r., No 3447 [The Law of Ukraine "On the Protection of animals from ill-treatment" of 02.21. 2006, No. 3447]. [in Ukrainian].

5. Kozhemiakin, Yu.M., Khromova, O.S., \& Filonenko, M.A. (2002). Naukovo-praktychni rekomendatsii z utrymannia laboratornykh tvaryn ta robota z nymy [Scientific and practical recommendations for the maintenance of laboratory animals and work with them]. Kyiv: Avitsena [in Ukrainian].

6. (1986). European convention for the protection of vertebrate animals used for experimental and other scientific purposes. Council of Europe. Strasbourg.
7. Wieland, H., \& Hallermayer, R. (1941). Uber die Giftstoffe des Knollenblatterpilzes. VI. Amanitin, das Hauptgift des Knollenblatterpilzes. R. Liebig's Ann. Chem., 548, 1-18.

8. Goryachkovskiy, A.M. (2005). Klinicheskaya biokhimiya $v$ laboratornoy diagnostike [Clinical biochemistry in laboratory diagnostics]. Odessa: Ekologiya [in Russian].

9. Andreichyn, M.A., Bekh, M.D., Demianenko, V.V., Nychyk, A.Z., \& Nychyk, N.A. (1998). Metody doslidzhennia endohennoi intoksykatsii orhanizmu: metod. rekomendatsii [Methods of study of endogenous intoxication of an organism: Methodical recommendations]. Kyiv [in Ukrainian].

10. Bernard Rosner. (2010). Fundamentals of biostatistics. Boston; USA.

11. Kuzmak, I.P. (2012). Osoblyvosti bilkovoho skladu krovi pry amanita-faloidynovomu otruienni [Features of blood protein composition at the amanita-phalloides intoxication]. Eksperymentalna ta klinichna fiziolohiia $i$ biokhimiia - Experimental and Clinical Physiology and Biochemistry, 2, 44-49.

\section{НЕКОТОРЫЕ ПОКАЗАТЕЛИ БЕЛКОВОГО ОБМЕНА У КРЫС, ОТРАВЛЕННЫХ БЛЕДНОЙ ПОГАНКОЙ}

\section{Резюме}

Вступление. Бледная поганка (Amanita phalloides) является одним из самых опасных ядовитых грибов. Токсины бледной поганки относят к сильным ядам, а учитывая отсутствие специфрических антидотов к ним, лечение отравлений этим грибом остается важной проблемой. Тяжелая клиническая картина отравлений бледной поганкой обусловлена токсическим поражением печени и почек, развитием острого гастроэнтероколита, возникновением эндотоксикоза, связанного с нарушением показателей гомеостаза и накоплением в организме токсических веществ эндогенного происхождения.

Цель исследования - изучить влияние яда бледной поганки на некоторые показатели белкового обмена у крыс.

Методы исследования. Исследования проводили на нелинейных белых 18-24-месячных крысах-самцах (период старости; старые). Отравляли животных путем однократного внутрибрюшного введения им экстракта бледной поганки, полученного по методу H. Wieland, в дозе 85 мг/кг массы тела. Эвтаназию крыс осуществляли путем декапитации под тиопенталовым наркозом через 6, 24 и 72 ч после отравления с дальнейшим забором крови. В сыворотке крови определяли концентрацию общего белка и белковых фрракций, креатинина и мочевины. Состояние эндогенной интоксикации оценивали по эритроцитарному индексу интоксикации и содержанию молекул средней массы.

Результаты и обсуждение. Установлено, что отравление экспериментальных животных токсинами бледной поганки приводило к существенным нарушениям белкового обмена. Наиболее выраженные изменения показателей белкового обмена наблюдали через 72 ч с момента интоксикации. У крыс отмечали снижение концентрации мочевины, повышение концентрации креатинина, гипопротеинемию, гипоальбуминемию, уменьшение содержания $\alpha_{1}-u \alpha_{2}$-глобулинов и возрастание содержания $\beta$ - и у-глобулинов. Наиболее выраженные изменения показателей эндогенной интоксикации были характерны через $244 \mathrm{c}$ момента интоксикации. 
Выводы. Полученные результаты свидетельствуют о резком негативном влиянии аманита-фраллоидинов на белоксинтезирующий аппарат гепатоцитов. Прогрессирование патологического процесса в печени и снижение компенсаторных возможностей приводят к эндотоксикозу, на что указывает возрастание в динамике показателей эндогенной интоксикации - эритроцитарного индекса интоксикации и содержания молекул средней массы.

КЛЮЧЕВЫЕ СЛОВА: бледная поганка; отравление; белковый обмен; крысы.

I. P. Kuzmak

I. HORBACHEVSKY TERNOPIL STATE MEDICAL UNIVERSITY

\title{
SOME PARAMETERS OF THE PROTEIN METABOLISM IN RATS AFTER AMANITA-PHALLOIDES INTOXICATION
}

\begin{abstract}
Summary
Introduction. Amanita phalloides is one of the most dangerous poisonous fungi in the world. Toxins of poison amanita refer to strong poisons, and because of the absence of specific antidotes to them, the treatment of these poisons remains an important problem. The severe clinical picture of poisoning of Amanita phalloides is due to toxic lesions of the liver and kidneys, the development of acute gastroenterocolitis, the emergence of endotoxicosis, associated with violation of homeostasis and accumulation in the body of toxic substances of endogenous origin.

The aim of the study - to reseach the effect of the poison of Amanita phalloides on some parameters of protein metabolism in rats.

Research Methods. The studies were conducted on non-linear white 18-24-month male rats (old age). The animals were poisoned by a single intraperitoneal administration of an extract of Amanita phalloides obtained by H. Wieland in a dose of $85 \mathrm{mg} / \mathrm{kg}$ body weight. After 6, 24 and 72 hours after poisoning, the concentration of total protein and protein fractions, creatinine and urea in blood serum was determined. The state of endogenous intoxication was assessed by the erythrocytic index of intoxication and the content of medium massmolecules.

Results and Discussion. It has been established that poisoning of experimental animals with toxins of Amanita phalloides leads to significant disorders of protein metabolism. The most pronounced changes in the protein metabolism are observed after 72 hours from the moment of intoxication. In rats, there is a decrease in urea concentration, increased creatinine concentration, hypoproteinemia, hypoalbuminemia, a decrease in the content of $\alpha_{1}$ - and $\alpha_{2}$-globulins and an increase in the $\beta$ - and $y$-globulin content have been observed. The most pronounced changes in the incidence of endogenous intoxication are characteristic after 24 hours from the moment of intoxication.

Conclusions. The obtained results testify about the marked negative effect of Amanita phalloides on the protein synthesizing system of hepatocytes. It was defined, that the progression of the pathological process in the liver and the depletion of the compensatory capacity cause the increasing of endogenous intoxication indices.
\end{abstract}

KEY WORDS: Amanita phalloides; poisoning; protein metabolism; rats.

Отримано 06.11.18

Адреса для листування: І. П. Кузьмак, Тернопільський державний медичний університет імені І. Я. Горбачевського, майдан Волі, 1 , Тернопіль, 46001, Україна, e-mail: kuzmak@tdmu.edu.ua. 